\title{
Anatomical Studies of Some Euphorbia species
}

\author{
Duaa M H Rezk ${ }^{1}$; El-sayed A.E.Abd El-aziz ${ }^{2}$; Sahar F.El-Hefnawy ${ }^{1}$; Hamz M.K. ${ }^{2}$ \\ 1- Al-Azhar University, Home Economics. Biological and Environmental Science Tanta. \\ 2- Azhar University, Faculty of Agriculture, Botany Department.
}

Corresponding author: duaarezk@yahoo.com

\begin{abstract}
This study include 32 species all belonging to the genus Euphorbia ( Euphorbiaceae).These samples collected from different floristic regions in Egypt. The anatomical studies occur on the stems of the plant samples and the characters are recorded comparatively for each species. The observations showed that the stems are mostly angled, the epidermis is often simple with one layer, the cortical layers of many species contained storage parenchyma, cells like palisade tissue. Transfer tissue, air cavities and idioblast also calcium oxalate observed in the cortex. The pith is solid in most samples and hollow in a few species.
\end{abstract}

Key word: Euphorbia, floristic, cortex, hollow

\section{Introduction}

Euphorbiaceae family is the sixth largest family, and one of the most several families of angiosperms, consisting of about 300 genera and over 8000 species (Radcliffe-Smith 1986). The largest genus is Euphorbia (spurge) consisting of over 1600 species (Evans and Taylor 1983), these species are more common in tropical areas all over the world. Its habitat ranges from herbs, shrubs to trees and cacti type. The genus Euphorbia is characterised by the presence of milky latex, being more or less toxic (Singia and Pathak 1990). This work aims to clear the variations between the stems structures of some Euphorbia species.

\section{Materials and methods}

\section{1- Materials}

Samples of plants representing genus Euphorbia were taken from 32 species. All materials were collected from various floristic regions in Egypt. The identification of the collected plants was achieved by comparing their morphological characters with the characters of the previously identified plants as published by Täckholm (1974), Migahid (1989) ) and Boulos (2000). The studied species arranged alphabetically in Table (1).

Table 1. Alphabetical list of (32) species representing the genus Euphorbia.

\begin{tabular}{|c|c|c|c|}
\hline No. & Species & No. & Species \\
\hline 1 & Euphorbia ambovombensis Rauh\&Razaf & 17 & E. mellifera Aiton \\
\hline 2 & E. caputa-medusae L. & 18 & E. milii var.splendens Des Moul \\
\hline 3 & E. cuneata Vahl. & 19 & E. obese Hook.f. \\
\hline 4 & E. deciduas Bally \& Leach & 20 & E. paralias L. \\
\hline 5 & E. fasciulata Thunb & 21 & E. peplus L. \\
\hline 6 & E. fimbriata Scop & 22 & E. polyacantha Boiss. \\
\hline 7 & E. grandicornis & 23 & E. pulcherrima Willd. ex Klotzsch. \\
\hline 8 & E. helioscopia L. & 24 & E. pulvinata Marloth \\
\hline 9 & E. heterophylla L. & 25 & E. retusa Forssk. \\
\hline 10 & E. hierosolymitana Boiss. & 26 & E. royleana Boiss. \\
\hline 11 & E. hirta L. & 27 & E. serpens Kunth \\
\hline 12 & E. hyssopifolia L. & 28 & E. suzannae Marloth \\
\hline 13 & E. indica Lam. & 29 & E. tirccalli Linné \\
\hline 14 & E. lacteacrestata Haw & 30 & E. tithymaloides L. \\
\hline 15 & E. lacteacandelabra & 31 & E. trigona Miller \\
\hline 16 & E. mammillaris L. & 32 & E. vansenvillrnsis \\
\hline
\end{tabular}

\section{2- Methods}

Parts of stem samples were fixed in F.A.A. for a minimum period of 48 hours. Stem samples were prepared by the method suggested by Sass (1958), sample of one centimeter long from the middle part of the technical length of the stem. Samples were dehydrated in series solutions of ascending concentrations of ethyl alcohol varying from $50 \%$ to $100 \%$ ethyl alcohol. The samples were then embedded in paraffin wax [m. p. 58-61c ${ }^{\circ}$ using xylol as solvent. By using rotary microtome, sections were cut at the thickness of 15 microns and then 
mounted on slides with the aid of egg- albumin as an adhesive. Wax dissolved in xylol and the slides were passed through descending series of ethyl alcohol solutions varying from $100 \%$ to $50 \%$ ethyl alcohol concentrations in descending order. The sections on the slides were stained with safranin and light green and then the colored sections were kept as permanent preparations on the slides with Canada balsam as mounting medium.

Sections in such cases were microscopically explored for the different microphotographs, which can be explored for the different tissues and components.

Table 2. List of (41) characters recorded comparatively for (32) Euphorbia spp. The characters were distinguished into (38) qualitative and (3) numerical characters respectively.

\section{A. Qualitative characters}

1- Outline shape: rounded (+) / angled (-)

2- Bark present (+) / absent (-)

3- Cuticle smooth (+) / rough (-)

4- Epidermis,hypodermis present (+) / absent (-)

5- “ prismatic crystals present $(+) /$ absent $(-)$

6- “ " druses crystals present (+) / absent (-)

7- “ agglomerated crystals present (+) / absent (-)

8- Cortex, cells like palsied present $(+) /$ absent (-)

9- “ " $\quad$ storage parenchyma present $(+) /$ absent $(-)$

10- “ " $\quad$ transfer tissue present $(+) /$ absent $(-)$

11- “ " sclerenchyma cells present $(+) /$ absent (-)

12- " " air cavities present $(+) /$ absent (-)

13- “ " laticifers canals present $(+) /$ absent $(-)$

14- " " idioblast present (+) / absent (-)

15- “ " " prismatic crystals present (+) / absent (-)

16- “ " druses crystals present (+) / absent (-)

17- “ " agglomerated crystals present (+) /absent (-)

18- “ cortical vascular bundles present (+) / absent (-)

19-Pericycle, only parenchyma cells $(+) /$ parenchyma with sclerenchyma-

20- “ idioblast present $(+) /$ absent $(-)$

21 - “ prismatic crystals present $(+) /$ absent $(-)$

22- “ " druses crystals present $(+) /$ absent $(-)$

23- “ laticifers present (+) / absent (-)

24- “ agglomerated crystals present (+) / absent (-)

25- Phloem, idioblast present (+) / absent (-)

26- “ laticifers present (+) / absent (-)

27- “ druses crystals present (+) / absent (-)

28- xylem, vessels in series present $(+)$ /in clusters $(-)$

29- “ prismatic crystals present $(+) /$ absent $(-)$

30- pith, sclernchymatus cells present $(+) /$ absent $(-)$

31- “ a aerenchyma cells present (+) / absent (-)

32- “ " storage parenchyma present (+) / absent (-)

33- “ " idioblast present (+) / absent (-)

34- “ d druses crystals present (+) / absent (-)

35- “ agglomerated crystals present (+) / absent ( - )

36 " a air cavities present $(+) /$ absent $(-)$

37- “ laticifers present (+) / absent (-)

\section{B - Numerical characters}

38-Stem cuticle layer, average thickness in $\mu$.

39- “ epidermal layer, average thickness in $\mu$.

40- “ xylem vessels, average dimension in $\mu$.

\section{Results and Discussion}

The investigation showed that, the stem varies in the outline shape, it is mostly angled e.g. Euphorbia heterophylla L (Fig.1), or rounded as in E. hirta $\mathrm{L}$ (Fig.2). The results are in harmony with the finding of Luz, et al (2015) who recorded that the stem transverse section showed a circular outline. The cuticle layer varies in thickness from $1.33 \mu \mu$ in $E$. trigona Miller to $17.33 \mu$ in E. obesa Hook.f. The cuticle is usually smooth or straight this showed in all studied samples e.g. E. heterophylla L (Fig.3), except in $E$. retusa Forssk which has rough cuticle (Fig.4). The average thickness of epidermal layer 
ranged between $5.26 \mu$ in E. heterophylla $\mathrm{L}$ to $26.33 \mu$ in E. obesa Hook.f. Epidermal layer is simple (present in one layer) in most of the examined species e.g. E. tithymaloides L (Fig.5), except two plant samples which have multiple epidermis (hypodermis) E. grandicornis and E. heterophylla $\mathrm{L}$ (Fig.3). Bark is observed in a few of the examined samples e.g. E. milii var.splendens Des Moul (Fig.6). These results are in agreement with those obtained by Kakkar and Paliwal.(1972), Watson and Dallwitz (1992) Gales \& Toma (2007), who recorded that the epidermis is covered by a cuticle of variable thickness, the stem cork was present.

In cortex the storage parenchyma are recorded in most examined samples e.g. E. mellifera Aiton (Fig.7). The chlorenchymatous cells like palisade tissue are noticed only in two samples E. tirucalli Linné and E. retusa Forssk (Fig.8). Transfer tissue is recorded in some examined samples as in E. lactea cristata Haw (Fig.9). And air cavities are also observed in the stem cortical. Idioblast present in some plants e.g. E. ambovombensis Rauh \& Razaf and laticifer present in some plants e.g. E. fasciulata Thunb (Fig.10). Cortical vascular bundles present in some plants e.g. E. caputa-medusae L (Fig.11). Prismatic crystals observed in the cortex of some plants. Agglomerate and druses crystals observed in the cortex of some plants. The investigation are both idioblast and laticifer canals in the stem cortical. These results are in agreement with those obtained by Jafari \& Nasseh (2009), Luković. et al (2009), Sultana (2017) who recorded that both the paranchyma and chlorenchyma cells were present in cortex of Euphorbia spp. Laticifer canals and storage parenchyma were also present in the cortex layer.
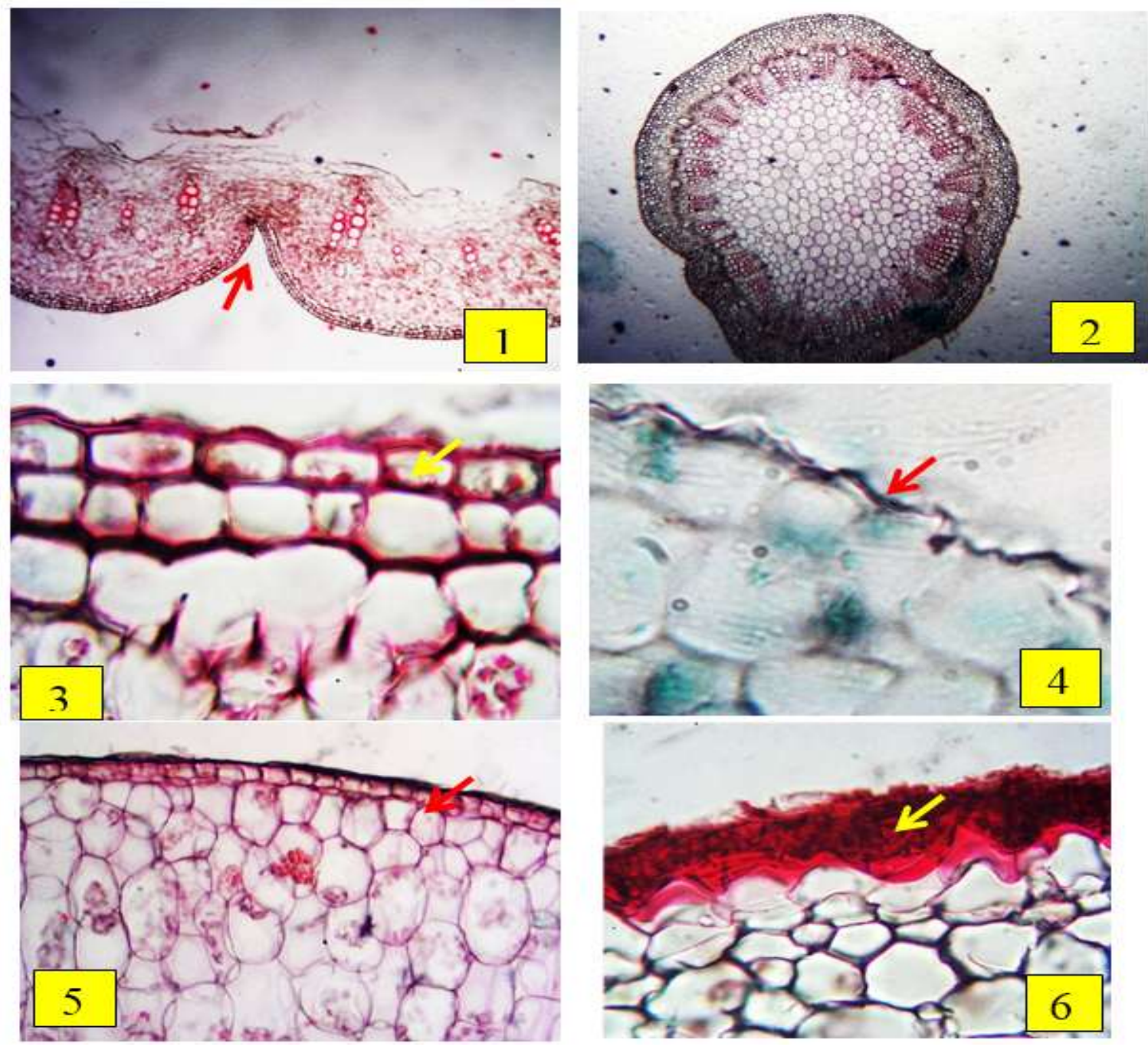

(Fig.1) T.S. of Euphorbia heterophylla L angled stem ( $\mathrm{x}=40)$.

(Fig.2) T.S of E. hirta L round stem (x=40).

(Fig.3) T.S of E. heterophylla L smooth cuticle and hypodermis (x=400).

(Fig.4) T.S of E. retusa Forssk rough cuticle (x=400).

(Fig.5) T.S of E. tithymaloides L. simple epidermis layer (x=200).

(Fig.6) T.S of E. milii var.splendens Des Moul Bark. (x=400). 


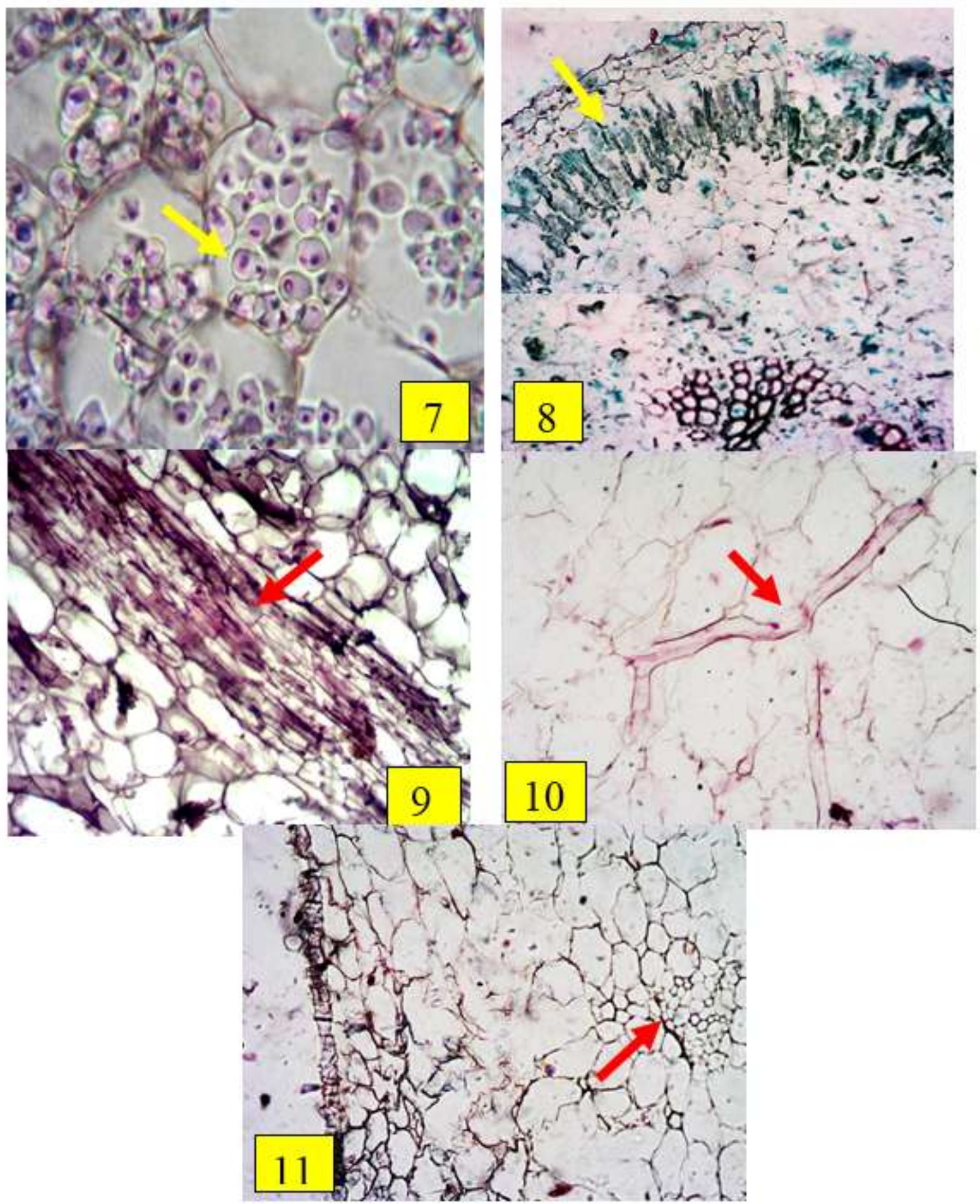

(Fig.7) T.S. of Euphorbia mellifera Aiton storage parenchyma (X=450)

(Fig.8) T.S of E. retusa Forssk Cells like palisade tissue $(\mathrm{X}=100)$

(Fig.9) T.S. of E. lactea cristata Haw transfer tissue (X=100)

(Fig.10). T.S. of Euphorbia fasciulata Thunb laticifer(X=100)

(Fig.11). T.S. of E. caputa-medusae L cortical vascular bundles (X=100)

The pericycle layer is usually consists of parenchymatous cells only, in this study some plant samples pericycle layer consists of parenchymatous cells accompanied with sclernchymatus cells e.g. $E$. serpens Kunth (Fig.12). Both Idioblast and laticifer canals are recorded in some examined samples e.g. E. hirta L (Fig.13). Also druses and prismatic crystals are observed in some studied samples in this layer. Agglomerate crystals are observed in some studied samples in this layer. The previous results are in harmony with the finding of Luković. et al (2009) who recorded that pericyclic groups of sclerenchyma tissue occur above the phloem region of vascular bundles. Laticifer canals are recorded in the pericycle 
layer. Idioblast cells and laticifer canals are recorded in the phloem of some examined samples also druse crystals are observed. The results are in harmony with the finding of Bercu,R. (2016) who recorded that in the phloem zone, few laticifers are present.

Xylem in most examined samples stems occur in series or arms such as E. hyssopifolia (Fig.14), while in other samples the vessels are in clusters, and few samples have the two states e.g. E. heterophylla L(Fig. 15). The average dimension of xylem vessels ranged between $9.4 \mu$ in E. suzannae Marloth and $80.8 \mu$ in E. heterophylla L. Most examined samples have solid stem e.g. E. tithymaloides L. (Fig. 16), while few species have hollow stem e.g. $E$. heterophylla L. (Fig.17). The stem pith is usually consists of parenchyma cells e.g. E. hirta L. (Fig.18),
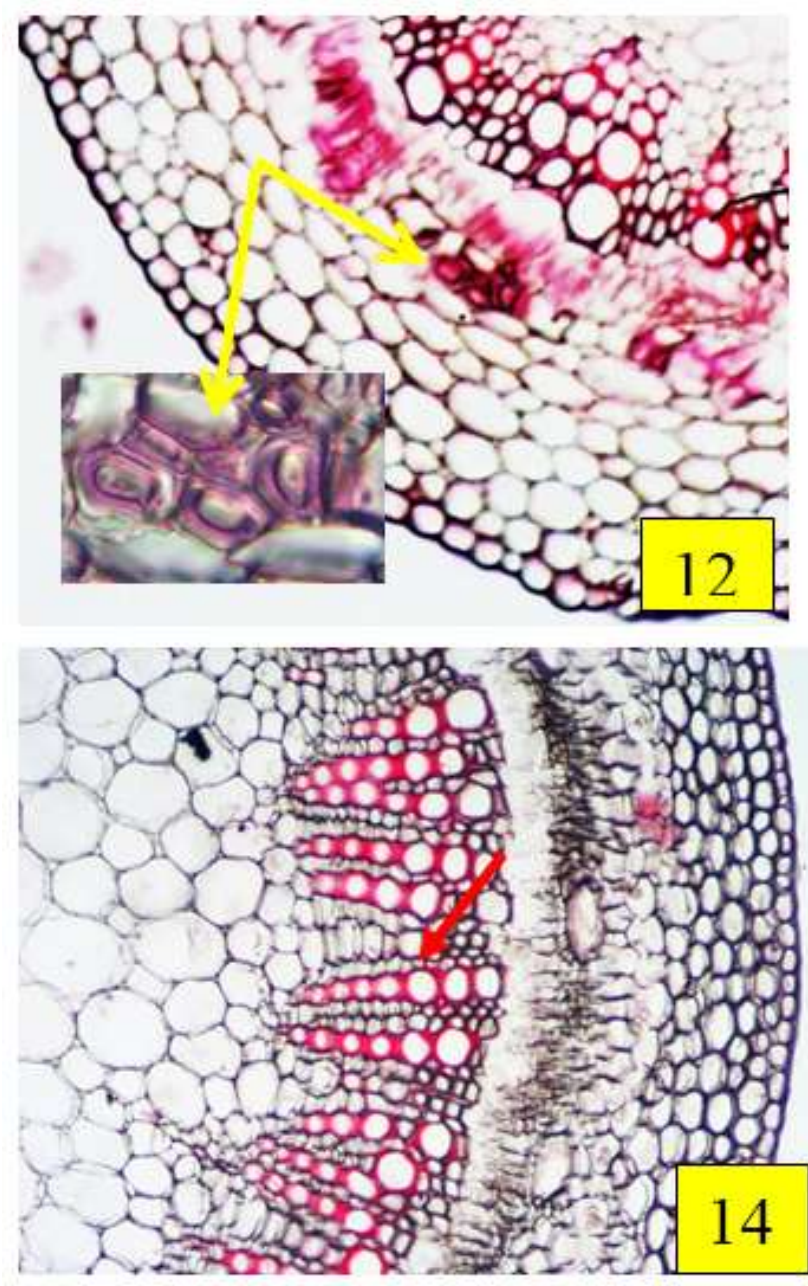

except in E. cuneata Vahl. (Fig. 19) has only sclernchyma cells. Also aerenchyma cells are recorded only in the pith of E. helioscopia L. (Fig.20). Many samples have storage cells in their pith e.g. E. tithymaloides L. Air cavities are also observed in the pith of some studied samples, both idioblast and laticifer canals are recorded in some species such as E. hirta (Fig.21). Prismatic oxalate crystals present in the pith of many samples e.g. $E$. milii var.splendens Des Moul (Fig.22). The results are in harmony with the finding of GALEŞ \&TOMA (2006), Gales \& Toma (2007), Zokian (2011) who recorded that the pith is parenchyma cells, having air cavities. In some samples pith often becomes hollow. Also laticiferes canals were observed in the pith.
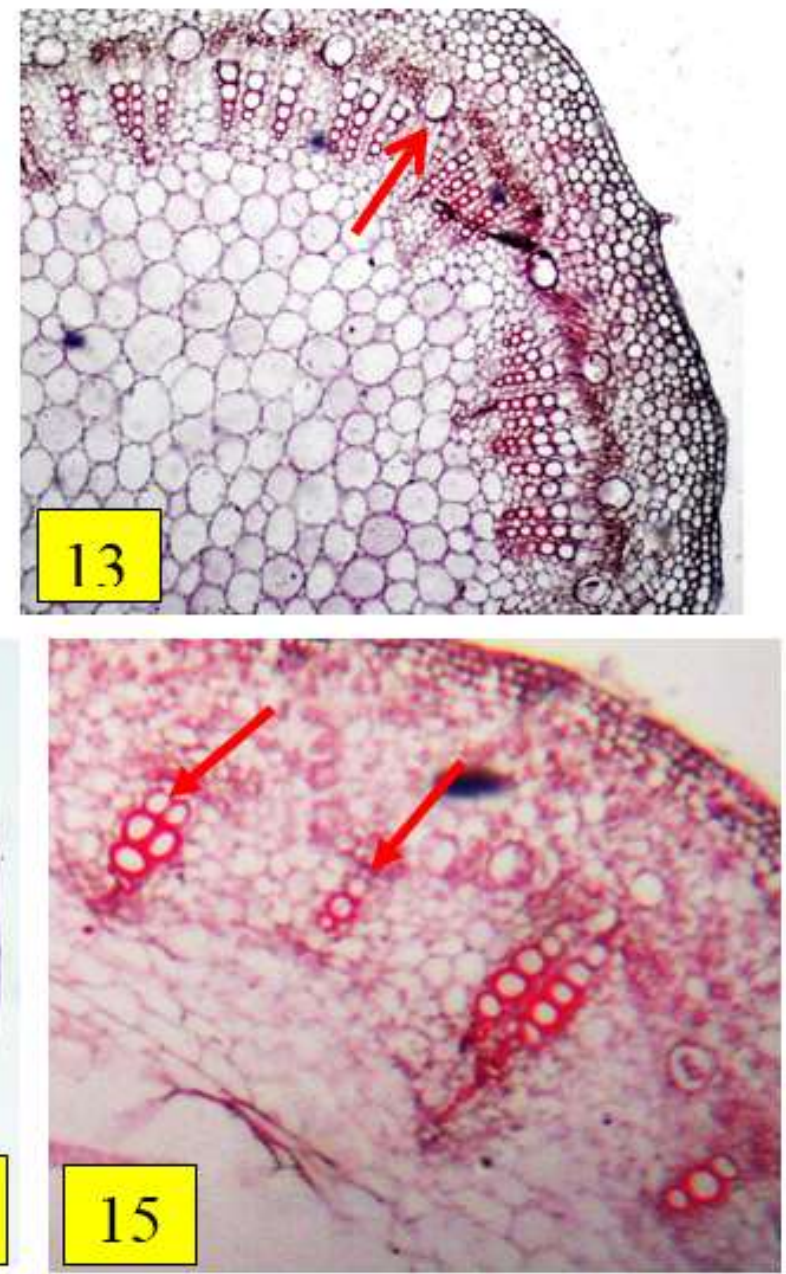

(Fig.12). T.S. of E. serpens Kunth sclernchymatus cells( $X=100-X=400)$

(Fig.13) T.S. of E. hirta L laticifer canals in pericycle layer $(X=100)$

(Fig.14) T.S. of Euphorbia hyssopifolia L xylem vessels in clusters (X=100)

(Fig.15) T.S. of E. heterophylla vessels in clusters and agglomeration $(X=100)$ 


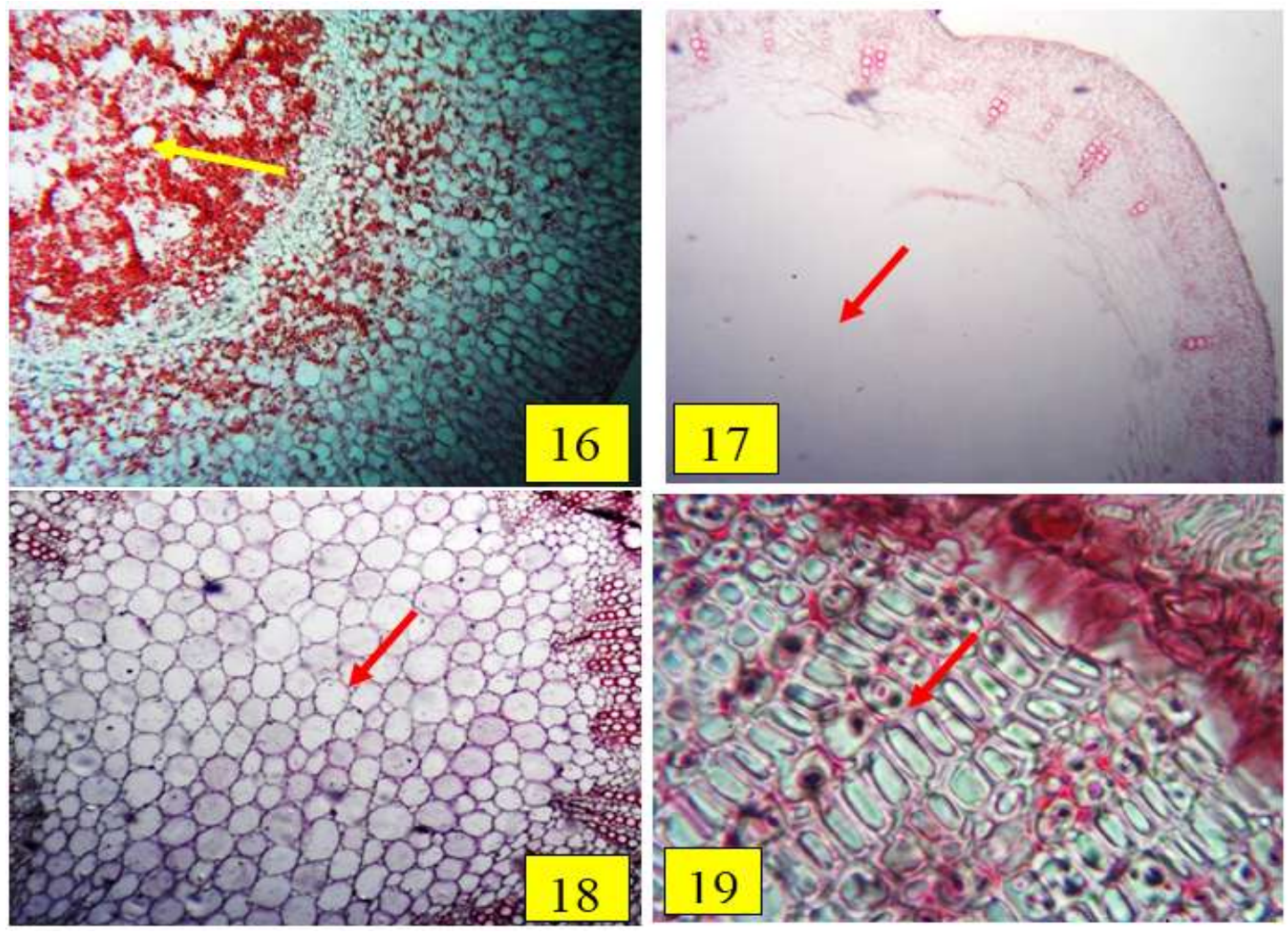

(Fig.16) T.S. of E. tithymaloides L solid stem $(\mathrm{X}=40)$

(Fig.17) T.S. of E. heterophylla L hollow stem (X=40)

(Fig.18) T.S. of Euphorbia hirta L parenchyma cells in the pith (X=40)

(Fig. 19) T.S. of E. cuneata Vahl sclernchyma cells in the pith $(\mathrm{X}=400)$

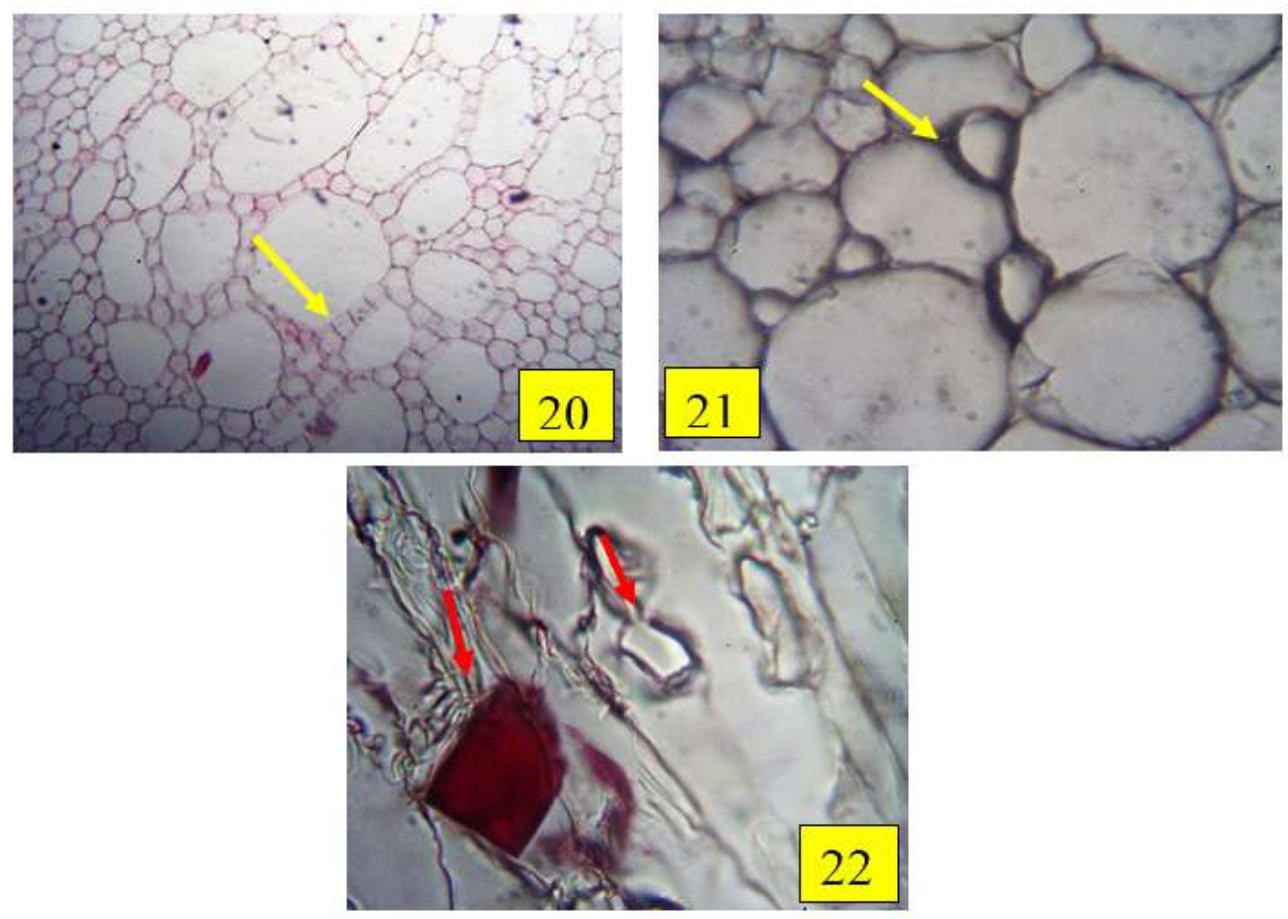

(Fig.20) T.S. of E. helioscopia $\mathrm{L}$ aerenchyma cells in the pith ( $\mathrm{X}=40)$

(Fig.21) T.S. of E. hirta $L$ laticifer canals in the pith . (X=400)

(Fig.22) T.S. of E. milii var.splendens Des Moul L. Agglomerate and prismatic crystals in the pith (X=400) 
Table (3). Data matrix of the (41) observed characters recorded comparatively for (32) species from genus Euphorbia. The characters were distinguished into (38) qualitative and (3) numerical. Missing characters denoted by $(*)$

\begin{tabular}{|c|c|c|c|c|c|c|c|c|c|c|c|c|c|c|c|c|c|c|c|c|c|c|c|c|c|c|c|c|c|c|c|c|c|c|c|c|c|c|c|c|}
\hline & 1 & 2 & 3 & 4 & 5 & 6 & 7 & 8 & 9 & 10 & 11 & 12 & 13 & 14 & 15 & 16 & 17 & 18 & 19 & 20 & 21 & 22 & 23 & 24 & 25 & 26 & 27 & 28 & 29 & 30 & 31 & 32 & 33 & 34 & 35 & 36 & 37 & 38 & 39 & 40 \\
\hline 1 & + & + & + & & - & + & & - & - & - & - & 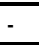 & + & + & - & + & - & - & + & - & + & + & - & - & - & - & - & \pm & - & & - & + & - & + & - & 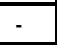 & & $*$ & $*$ & 13.4 \\
\hline$\sqrt{2}$ & - & - & + & - & - & - & - & - & - & - & - & - & + & - & - & - & - & + & + & - & - & - & - & - & - & - & - & + & - & - & - & - & - & - & - & - & - & 3.6 & 18 & 8.1 \\
\hline 3 & + & - & - & . & - & - & & - & - & - & - & - & + & + & - & - & - & + & + & - & - & - & - & - & - & - & - & + & - & + & - & - & - & 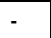 & - & - & - & 1.86 & 10.4 & 17.66 \\
\hline$\overline{4}$ & - & - & + & & - & - & - & - & - & + & - & - & + & - & - & - & - & + & + & - & - & & + & - & - & $\overline{-}$ & - & \pm & $\overline{-}$ & $\overline{-}$ & - & - & - & - & - & - & + & 3.8 & 19.1 & 9.8 \\
\hline 5 & - & - & + & - & - & - & - & - & - & + & - & - & + & + & - & - & + & + & + & + & - & - & - & - & + & - & - & - & - & - & - & - & + & - & - & - & + & 6.13 & 18.66 & 14.93 \\
\hline 6 & - & - & + & - & + & - & - & - & - & + & - & - & + & + & - & - & - & + & + & - & - & - & - & - & - & - & - & + & - & - & - & - & - & - & - & - & + & 2.6 & 17.13 & 16.66 \\
\hline 7 & - & - & + & + & - & - & - & - & - & - & - & + & + & - & - & - & - & + & + & - & - & - & - & - & - & - & - & - & - & - & - & - & + & - & - & + & + & 2.53 & 13.13 & 17.26 \\
\hline$\overline{8}$ & + & - & + & - & - & - & - & - & - & - & - & + & + & - & - & - & - & - & + & - & - & - & - & - & - & - & - & + & - & - & + & - & - & - & - & - & - & 5.33 & 23 & 18.53 \\
\hline 9 & - & - & + & + & - & - & - & - & + & - & + & + & + & - & - & - & - & - & + & - & - & - & + & - & - & - & - & \pm & + & - & - & - & - & - & - & - & - & 2.6 & 5.26 & $\begin{array}{l}80.8 \\
\end{array}$ \\
\hline 10 & + & + & - & - & - & - & - & - & + & - & - & - & - & - & - & - & - & - & - & - & - & - & - & + & - & - & - & + & - & - & - & + & - & - & - & - & - & 2 & 10 & 21.2 \\
\hline 11 & + & - & + & - & - & - & - & - & - & - & - & - & + & + & - & - & - & - & + & - & - & - & + & - & - & + & - & + & - & - & - & - & - & - & - & - & + & 1.86 & 12.86 & 22.6 \\
\hline 12 & + & - & + & - & - & - & - & - & + & - & - & - & + & + & - & - & - & - & + & - & - & - & + & - & - & + & - & + & - & - & - & - & - & - & - & + & + & 2.73 & 12.6 & 12.46 \\
\hline 13 & + & - & + & - & - & - & - & - & + & + & - & - & - & - & - & - & - & - & - & - & - & - & - & - & - & - & - & + & - & - & - & + & - & - & - & - & - & 1.4 & 5.53 & 22.13 \\
\hline 14 & - & - & + & . & - & - & - & - & + & + & - & + & + & + & - & - & - & + & + & + & - & - & + & - & - & + & - & \pm & - & - & - & - & + & - & - & - & + & 2.26 & 23.4 & 10.86 \\
\hline 15 & - & - & + & - & - & - & - & - & + & - & - & - & + & + & - & - & - & + & + & - & - & - & - & - & - & - & - & - & - & - & - & - & + & - & - & - & - & 3.13 & 25 & 15.4 \\
\hline 16 & - & - & + & - & - & - & - & - & + & + & - & - & + & + & - & - & - & + & + & + & - & - & + & - & - & - & - & \pm & - & - & - & - & - & - & - & - & + & 2.73 & 23.8 & 14.4 \\
\hline 17 & + & - & + & - & - & - & - & - & + & + & - & - & + & + & + & - & + & + & + & - & - & - & + & - & - & + & - & \pm & - & - & - & + & - & - & - & - & + & $*$ & $*$ & 35.6 \\
\hline 18 & - & + & - & - & - & - & - & - & - & - & - & - & - & + & + & - & + & + & + & - & - & - & - & - & - & - & - & + & + & - & - & - & - & - & - & - & + & $*$ & $*$ & 25.33 \\
\hline 19 & - & - & + & - & - & - & - & - & + & + & - & - & + & + & - & - & - & - & + & - & - & - & - & - & - & - & - & - & - & - & - & - & + & - & - & - & + & 17.33 & 26.33 & 20.4 \\
\hline 20 & + & - & + & - & - & - & - & - & - & - & - & - & + & - & - & - & - & + & + & - & - & - & - & - & - & - & - & + & - & - & - & - & - & - & - & - & - & 5.7 & 18.3 & 32.5 \\
\hline 21 & + & - & + & - & - & - & - & - & - & - & - & - & + & + & - & - & - & - & + & - & - & - & - & - & - & - & - & \pm & - & - & - & - & - & - & - & - & - & 1.7 & 18.7 & 22.8 \\
\hline 22 & - & - & + & - & - & - & - & - & + & - & - & + & + & + & - & - & - & + & + & + & - & - & + & - & - & - & - & - & - & - & - & - & + & - & - & - & + & 4 & 18.93 & 13.8 \\
\hline 23 & + & - & - & - & - & - & + & - & - & - & - & - & + & + & - & - & + & - & + & + & - & - & - & - & + & - & - & \pm & - & - & - & - & + & - & - & - & - & 1.93 & 12.93 & 43.73 \\
\hline 24 & - & - & + & - & - & - & - & - & + & + & - & + & + & + & - & - & + & - & + & - & - & - & - & - & - & - & - & \pm & - & - & - & + & - & - & - & + & + & 6.86 & 16.86 & 15 \\
\hline 25 & + & - & - & - & - & - & - & + & - & - & - & + & - & + & - & - & - & + & + & - & - & - & - & - & - & - & - & \pm & - & - & - & - & + & - & - & - & - & 1.86 & 19.53 & 29.93 \\
\hline 26 & - & - & - & - & - & - & - & - & + & - & - & + & + & + & - & - & - & + & + & - & - & - & - & - & - & \begin{tabular}{|l}
- \\
\end{tabular} & - & \pm & - & - & - & - & + & - & - & - & + & 1.6 & 16.86 & 27.66 \\
\hline 27 & + & - & - & - & - & - & - & - & - & - & + & - & + & - & - & - & - & - & + & - & - & - & - & - & - & - & - & \pm & - & - & - & \begin{tabular}{|l|}
- \\
\end{tabular} & - & - & - & - & - & 1.93 & 13.86 & 24.53 \\
\hline 28 & - & - & + & - & - & - & - & - & + & + & - & - & + & + & - & - & - & + & + & - & - & - & + & - & - & - & - & - & - & - & - & - & - & - & - & - & + & 4 & 14.73 & 9.4 \\
\hline 29 & + & - & - & - & - & - & - & + & - & - & - & + & - & + & - & - & - & - & + & - & - & - & - & - & - & - & - & \pm & - & - & - & - & - & - & - & - & - & 2.8 & 11 & 19.6 \\
\hline 30 & + & - & + & - & - & - & - & - & + & - & - & - & + & + & - & - & - & - & + & - & - & - & + & - & - & + & - & \pm & - & - & - & - & + & - & - & + & + & 1.93 & 13.8 & 18.73 \\
\hline 31 & - & - & + & - & - & - & - & - & - & + & - & - & + & + & - & - & - & + & + & \begin{tabular}{|l}
- \\
\end{tabular} & - & - & - & - & - & + & - & \pm & - & - & - & \begin{tabular}{|l}
- \\
\end{tabular} & - & - & - & - & + & 1.33 & 9 & 10.26 \\
\hline 32 & - & - & + & - & - & - & 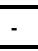 & - & + & + & - & + & + & + & - & - & - & - & + & \begin{tabular}{|l|}
- \\
\end{tabular} & - & - & + & - & - & - & - & \pm & - & - & - & \begin{tabular}{|l|}
- \\
\end{tabular} & + & - & - & + & + & 7.46 & 17.53 & $\begin{array}{l}19.6 \\
\end{array}$ \\
\hline
\end{tabular}




\section{References}

Bercu R. (2016). Comparative anatomical aspects of Euphorbia milli var. splendens (Bojer ex Hook)Ursch\& Leandri and Euphorbia pulcherima Willd . Ex klotzsch species leaves. Annals of West University of Timişoara, ser. Biology, 2016, vol. 19 (2), pp.157-166.

Boulos L. (2000). Flora of Egypt vol.2. Al hadara publishing, Cairo-Egypt. pp: 36-67.

Evans F. J. and Taylor S. E. (1983). In Progress in the Chemistry of Organic Natural Products; W. Herz, H. Grisebach, G.W. Kirby Eds.; SpringerVerlag:Wien, New York; volume 44, p. 1-99.

Gales R C. and Toma C. (2007). Comparative anatomy of the vegetative organs of some Euphorbia species (Euphorbiaceae juss) from the Romanian flora. Rom. J. Biol. Plant Biol. Volumes 51-52, P. 39-47.

Gales R. C. and Toma C. (2006). Histo-Anatomical data of some Euphorbia species from the Romanian Flora. Analele ştiinţifice ale Universităţii “Al. I. Cuza” Iaşi.

Jafari A. and Nasseh Y. (2009). An Internal Structure Investigation on Euphorbia L.Species in North-East of Iran. Asian Journal of Plant Sciences 8 (1): 86-88.

Kakkar L. and Paliwal G. S. (1972). Studies on the leaf anatomy of Euphorbia. Department of Botany,University of Delhi, Delhi-110007.

Luković J., Malenčić D., Zorić L., Kiprovski B., Merkulov L., and Boža P.(2009). Anatomical characteristics and antioxidant properties of
Euphorbia nicaeensis ssp. Glareosa. Cent. Eur. J. Biol. • 4(2) • PP 214-223.

Luza L.E.C., Paludo K.S., Santos V.L.P., Kati S., Franco C.R.C., Klein T., Silva R.Z., Beltrame F. L. and Budel J. M. (2015). Cytotoxicity of latex and pharmacobotanical study of leaves and stem of Euphorbia umbellata (Janaúba). Revista Brasileira de Farmacognosia 25 .PP 344-352.

Migahid A. M. (1989). Flora of Saudi Arabia . Sec .edition, published by Unive. Libraries , King Saud , Unive . S.A.K. pp.152-178.

Radcliffe-Smith A. (1986). In Naturally Occurring Phorbol Esters; Evans F. J.,Ed.; CRC Press, Inc.: Boca Raton, Florida; chapter 3, p. 63-85.

Sass J .E. (1958). Botanical microtechnique. The Iows state Universiy press Iowo, U.S.A.

Singia, A.K. and K. Pathak. (1990). Fitoterapia, LXI. 483-516.

Sultana R .S (2017). Anatomical Characteristics of Stem and Leaf in Euphorbia hirta L. Science publishing group Plant. Vol. 5, No. 1, pp. 9-12.

Tackholml V. (1974). Student's flora of Egypt (2nd ed). Cairo University: Cooperative Printing Co. Beirut. pp 425-430.

Watson L., and Dallwitz, M.J. (1992). The families of flowering plants: descriptions, illustrations, identification and information retrieval. deltaintkey.com

Zokian S.Y. (2011). Biosystematics of four species of Euphorbia L. Grown in Baghdad University Campus- Jadiriyah. Republic of Iraq Ministry of Higher Education and Scientific Research University of Baghdad College of Science Biology Department.

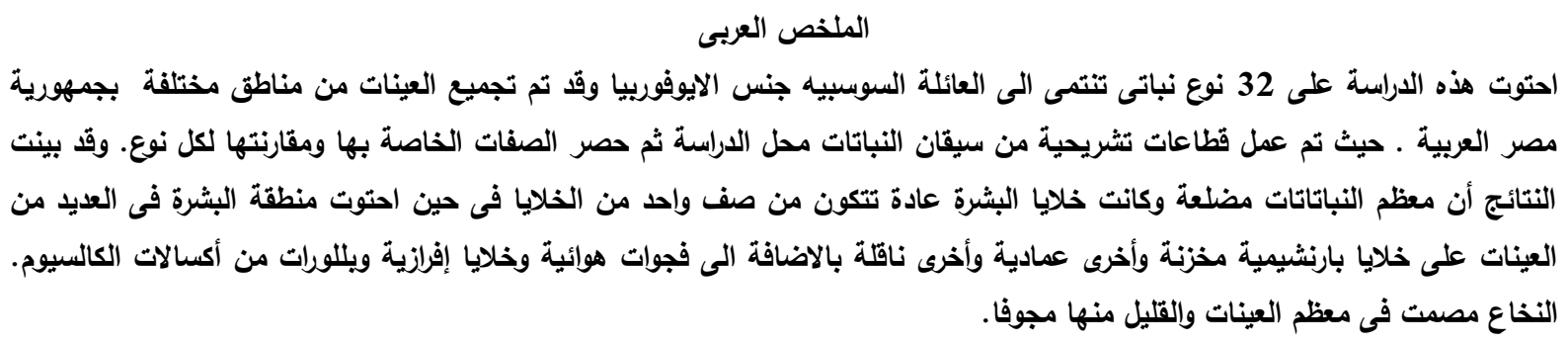

